\title{
D 15 環状シンセティック・ジェット・アクチュエータによる 円形噴流の混合促進（励起周波数の影響） \\ Enhanced Mixing of a Circular Jet Using an Annular Synthetic Jet Actuator - Effect of Excitation Frequency -
}

\author{
正 高曾 徹（九州大） ○学 木下 卓也（九州大）
}

Toru KOSO, Institute for Materials Chemistry and Engineering, Kyushu University, 6-1Kasuga-koen, Kasuga-shi, Fukuoka Takuya KINOSHITA, Interdisciplinary Graduate School of Engineering Sciences, Kyushu University

Key Words: Synthetic Jet, Turbulent Jet, Mixing Enhancement, Piezoelectric Actuator

\section{1.はじめに}

シンセティック・ジェット・アクチュエータ（Synthetic Jet Actuator）とはスリットから高周波数の往復振動流を噴出・吸 引させて, 噴流を発生させる装置である(1). 正味の流出流量 は零であるが流れ場に平均流や乱れを生じさせる。この装置 をはく離の能動制御 ${ }^{(2)}$, 噴流の方向制御 ${ }^{(3)}$, 流れの混合促進 (4)-(6)など応用するための研究が進められている.

著者ら ${ }^{(4)(6)}$ は先に円形噴流に同軸の環状シンセティック・ジ エット・アクチュエータを取り付けて実験し, 噴流の混合が 促進されることを示した。一般に，噴流は高乱流で混合能の 高い流れであるが，レイノルズ数が低下すると混合層の発達 開始が下流に移行するためノズル近くでの混合は小さくなる. そのためマイクロ・バーナなどの小形流動装置の混合促進に このアクチュエータが有効と期待される.

本報告では比較的に低レイノルズ数の円形乱流噴流に同軸 の環状シンセティック・ジェット・アクチュエータを取り付 けて実験した．特に，アクチュエータを駆動する周波数を変 えて実験し，円形噴流の平均速度場に及ぼす影響を調べた。

\section{2. 実験装置および方法}

図 1 に本実験で用いた噴流装置 ${ }^{(4)(6)}$ の形状を示す. 図 1 (a) に噴流ノズルの側面の断面図を, 図 1 (b)に正面図を示す。中 央に円形噴流（主噴流）用の円管があり，その周りにシンセ ティック・ジェット・アクチュエータ（圧電振動板, 空洞, 環状隙間）が設置されている. 円形噴流は内径 $d=5.0 \mathrm{~mm}$, 外 径 $d_{1}=6.0 \mathrm{~mm}$, 長さ $76 \mathrm{~mm}$ のステンレス円管から噴出させた. 内側径 $d_{1}=6.0 \mathrm{~mm}$ (円管の外径), 外側径 $d_{2}=7.9 \mathrm{~mm}$ の環状隙間 から往復脈動流を流出させた. 環状隙間の板厚は $0.85 \mathrm{~mm}$ で ある. 圧電振動板の振動によって空洞内空気が駆動され, 環 状隙間に往復脈動流が発生する. 圧電振動板は直径 $31.2 \mathrm{~mm}$, 厚さ $0.1 \mathrm{~mm}$ の鉄ニッケル板にピエゾ・セラミックを貼り付け たものである.これに正弦波交流電圧を印加した.

I 形熱線プローブをトラバースして噴流中の速度 $u$ の分布 を計測した．熱線流速計の出力電圧信号はアンチ・エイリア シング・フィルタに通した後 16 ビット $\mathrm{AD}$ 変換ボードで $10 \mathrm{kHz}$ でサンプリングしてパソコンに取り込んだ. サンプル 長は 3.2 秒であり, それから平均速度, 乱れ速度を求めた。

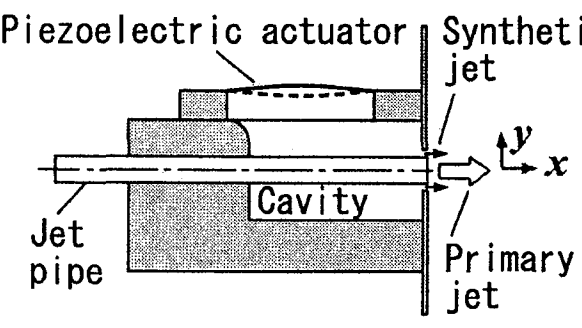

(a) side view

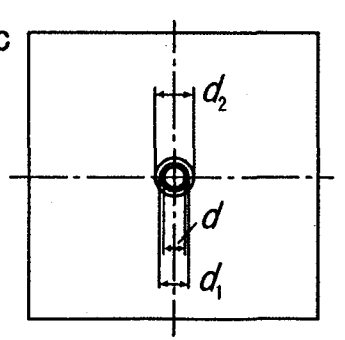

(b) front view
Fig. 1 A circular jet with a coaxial annular synthetic jet actuator.
3. シンセティック・ジェット・アクチュエータの周波数特性 まず始めにアクチュエータを駆動する周波数 (励起周波数) が環状隙間の往復脈動流に及ぼす影響を調べた。圧電振動板 への印加電圧を $\mathrm{AC} 42.0 \mathrm{~V}$ に保ち, 励起周波数を $50 \sim 2000 \mathrm{~Hz}$ で変化させ，環状隙間中央での脈動速度（速度 $\mathrm{rms}$ 值） $u_{\mathrm{s}}{ }^{\prime}$ を 計測した。

図 2 に往復脈動流の脈動速度に及ぼす励起周波数の影響を 示す. 周波数によって脈動速度が大きく変化することが分か る. $750 \mathrm{~Hz}$ のピークは圧電振動板の共振振動数であり, $1050 \mathrm{~Hz}$ 付近の山はへルムホルツ共鳴によるものと考えられる。

図 2 の周波数特性を基に脈動速度がほぼ同じ $600 \mathrm{~Hz}, 800 \mathrm{~Hz}$, $1000 \mathrm{~Hz}$ の 3 条件についてシンセティック・ジェットの速度分 布を調べた. 図 3 にノズルから $25 \mathrm{~mm}$ 離れた位置での速度分 布を示す、いずれも噴流の流れ場が形成されており，その速 度の大きさ・分布はほぼ同じであることが分かる. シンセテ イック・ジェットの強さは脈動速度が同じであれば周波数に よって変化しないものと考えられる.

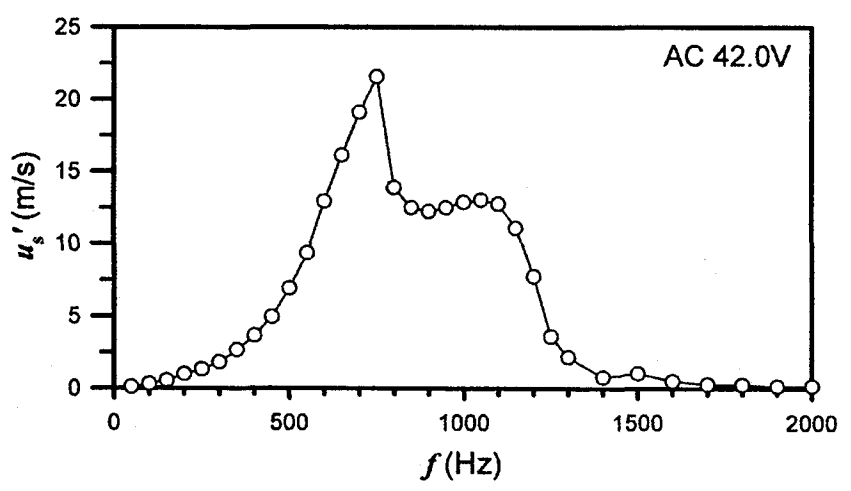

Fig. 2 Effect of excitation frequency on the rms velocities of alternating flow in the annular gap.

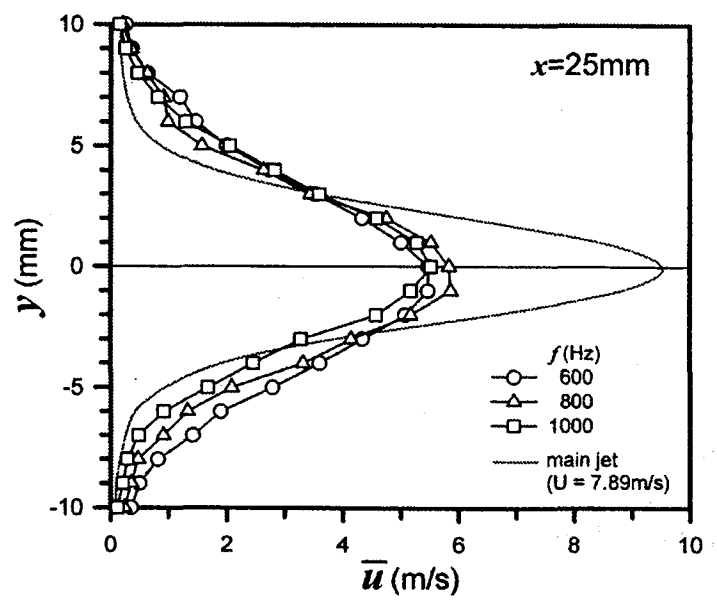

Fig. 3 Velocity profiles generated by annular synthetic jet actuator. 


\section{4. 円形噴流の混合促進実験}

主噴流の噴出速度は $U=7.89 \mathrm{~m} / \mathrm{s}$ で行った. その噴出レイノ ルズ数は $R e=U d / v=2760$ であり, 乱流円管流を噴出させた. 円管出口中心での平均速度は $\bar{u}_{m 0}=10.4 \mathrm{~m} / \mathrm{s}$ で, 相対乱れ度は $u^{\prime} / \bar{u}_{m 0}=0.057$ であった. アクチュエータの励起周波数は $f=$ $600,800,1000 \mathrm{~Hz}$ で実験した. その脈動速度，ストローハル 数はそれぞれ $u_{\mathrm{s}}{ }^{\prime}=13.0,13.9,12.9 \mathrm{~m} / \mathrm{s}, S t=f d \bar{u}_{m 0}=0.288,0.385$, 0.481 である. 励起しない円形噴流のスペクトル計測からこの 噴流の大規模渦構造の周波数は $f=840 \mathrm{~Hz}$ 程度と考えられる. 図 3 のシンセティック・ジェット速度分布に主噴流の分布も 示す. 本実験条件のシンセティック・ジェットは主噴流の流 れと同程度の強さを有していることがわかる.

4.1 平均速度場 図 4〜 7 に主噴流だけと励起した噴流の 等速度分布を示す. 図中の数字は速度 $\bar{u}(\mathrm{~m} / \mathrm{s})$ を表している. なお，熱線流速計では瞬間的な逆流を正しく計測できないの で，環状隙間直後での速度は示していない。

図 4 に主噴流だけ（励起なし：脈動速度 $u_{\mathrm{s}}{ }^{\prime}=0$ ）の平均速度 の等速度分布を示す. 噴流の幅は $x=15 \mathrm{~mm}(x / d=3)$ 程度ま で一定で，その後拡大することがわかる.

図 5〜7に主噴流をシンセティック・ジェット・アクチュ エータで励起した噴流の等速度分布を示す. 励起周波数はそ れぞれ $f=600,800,1000 \mathrm{~Hz}$ である. いずれの励起周波数の場 合も噴流は流れ場全域で拡がることがわかる. また, 励起周 波数の影響は $x=15 \mathrm{~mm}(x / d=3)$ 程度までの分布に見られる が，それより下流ではほとんど同じ分布を示す. $800 \mathrm{~Hz}$ の励 起は噴流の大規模渦構造の周波数と近いにもかかわらず他の 周波数の励起と同じであった.このことから, 大規模渦構造 を強化するような作用は生じなかったと考えられる.

また, $x=40 \mathrm{~mm}(x / d=8)$ の分布を図 4 の励起のない噴流 と比較すると中心速度はほぼ同じであるが噴流幅が拡がって いるこ之が分かる.これは，シンセティック・ジェットの運 動量の付与によって流れの運動量が增したためと考えられる. 4.2 最大速度 - 半值幅 噴流中心軸上の最大速度（図示な し）と半值幅（図 8) の流れ方向の変化を検討した. 励起噴 流は励起しない噴流より，最大速度は小さいか同じであり， 半値幅は広くなった。 励起周波数による最大速度・半值幅の 違いは $x=15 \mathrm{~mm}$ 程度まで見られたが，下流では同じになった。

\section{5.まとめ}

シンセティック・ジェット・アクチュエータで励起した円 形噴流は噴流幅が大きくなり混合促進された. 励起の脈動速 度が同じ場合，励起された噴流の幅は励起周波数によらずほ ぼ同じであることがわかった．また，噴流の大規模瀜構造の 周波数に近い $800 \mathrm{~Hz}$ の励起に違いは認められなかった.

\section{参考文献}

(1) Glezer, A. and Amitay, M., Synthetic Jets, Ann. Rev. Fluid Mech., 34, (2002) 503-529.

(2) Gilarranz, J.L. and Rediniotis, O.K., Compact, High-Power Synthetic Jet Actuators for Flow Separation Control, ALAA paper 2001-0737 (2001).

(3) Smith, B.L. and Glezer, A., Jet vectoring using synthetic jets, $J$. Fluid Mech. 458 (2002) 1-34.

(4) 高曾・ほか, 円形噴流に及ぼす同軸環状シンセティック・ ジェットの影響, 機講論 No.04-25(2004), 238, CD-ROM.

(5) 高曾・白石, シンセティック・ジェットによる二次元噴 流の混合促進, 機講論 No.058-1(2005), 353-354.

(6) Koso, T., Enhanced Mixing of a Circular Jet Using an Annular Synthetic Jet Actuator, Jets, Wakes and Separated Flows, JSME No.05-201 (2005), 385-390.

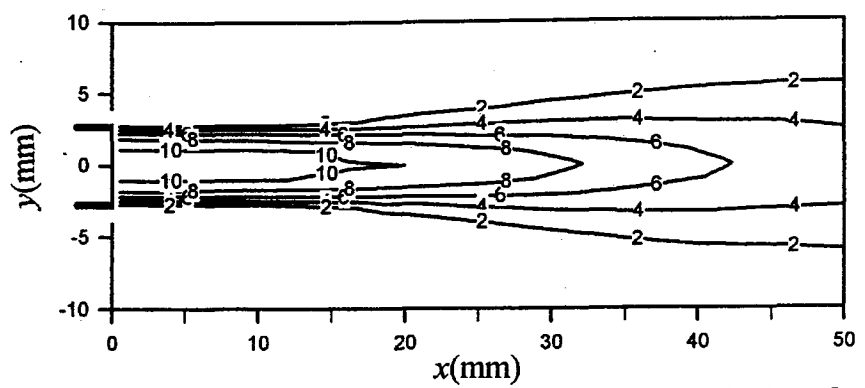

Fig. 4 Iso-velocity contour map for time-averaged velocity of a jet without excitation.

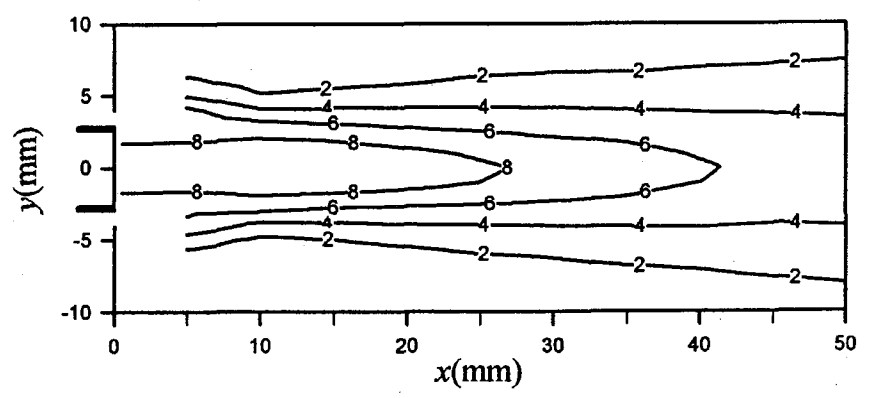

Fig. 5 Iso-velocity contour map for time-averaged velocity of a jet with excitation (excitation frequency $f=600 \mathrm{~Hz}$ )

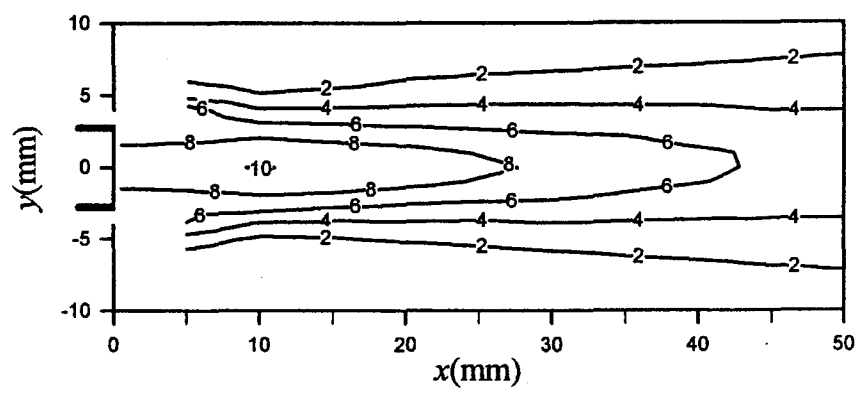

Fig. 6 Iso-velocity contour map for time-averaged velocity of a jet with excitation (excitation frequency $f=800 \mathrm{~Hz}$ )

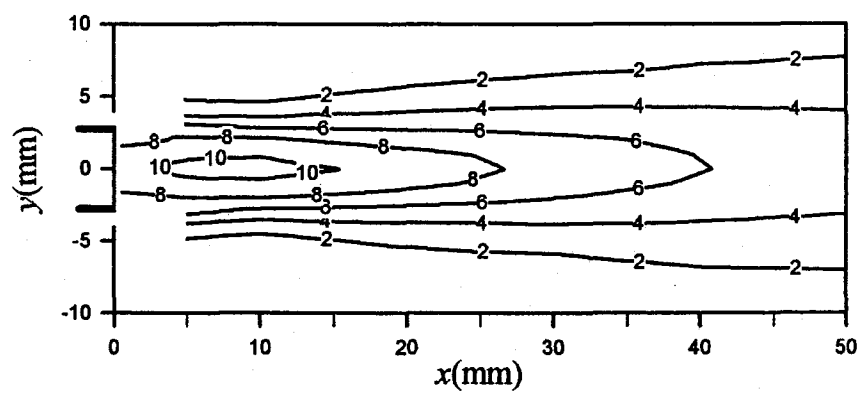

Fig. 7 Iso-velocity contour map for time-averaged velocity of a jet with excitation (excitation frequency $f=1000 \mathrm{~Hz}$ )

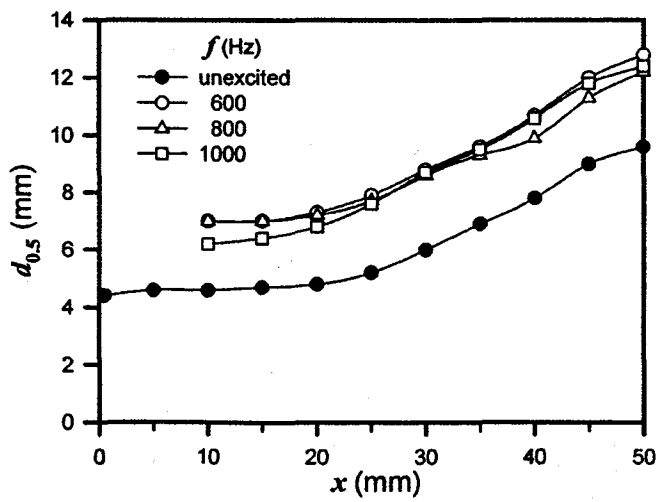

Fig. 8 Growth of half-width of the jet. 